\title{
Conditioned food aversion to control Palicourea aeneofusca poisoning
}

\author{
Aversão alimentar condicionada para o controle da intoxicação por Palicourea aeneofusca
}

\author{
Murilo Duarte Oliveira ${ }^{I}$ Franklin Riet-CorreaII Genilson Barbosa da Silva ${ }^{\mathrm{I}}$ \\ Walkleber dos Santos Pereira ${ }^{\mathrm{I}}$ Luis Flávio Souza Freire ${ }^{\mathrm{I}}$ Rosane Maria Trindade Medeiros ${ }^{\mathrm{II}^{*}}$
}

\section{- NOTE -}

\section{ABSTRACT}

Palicourea aeneofusca contains sodium monofluoroacetate, which causes sudden death in ruminants when administered at doses of approximately $0.6 \mathrm{~g} \mathrm{~kg}^{-1}$ of body weight $\left(\mathrm{g} \mathrm{kg}^{-1}\right)$. In this experiment two groups of 6 goats were used to determine the possibility to induce conditioned food aversion to P. aeneofusca. In group 1, $0.35 \mathrm{~g} \mathrm{~kg}^{-1}$ of green leaves of the plant were given to six goats on days 1, 5, 10, 20, 30, 60, and 90 of the experiment. On the first day, all of the goats ingested the full amount of the plant and were treated immediately with $175 \mathrm{mg} \mathrm{kg}^{-1}$ of lithium chloride ( $\mathrm{LiCl}$ ) through a ruminal tube. On day 5, only two goats ingested the plant, and they were treated with the same dose of LiCl. On days 10, 20, 30, 60, and 90, none of the goats ingested the plant. For another group of 6 goats, the leaves were given on days 1, 10, 20,30,60, and 90. All of the goats ingested the leaves on day 1 and received $1 \mathrm{~mL} \mathrm{~kg}^{-1}$ body weight of water through a ruminal tube. All of these goats ingested the plant on days 10, 20, 30, 60, and 90. These results demonstrate that it is possible to induce conditioned food aversion to $\boldsymbol{P}$. aeneofusca that persists for at least 90 days. Further experiments should be performed to determine the duration of the aversion and to induce aversion to other Palicourea species, particularly P. marcgravii, which is the most important toxic plant in Brazil.

Key words: poisonous plants, Palicourea spp., sodium monofluoroacetate, conditioned food aversion.

\section{RESUMO}

Palicourea aeneofusca, que contém
monofluoroacetato de sódio, causa morte súbita em ruminantes
quando é administrada a doses de aproximadamente $0,6 \mathrm{~g}^{-1}$ de
peso vivo $\left(\mathrm{g} \mathrm{kg}^{-1}\right)$. Neste experimento, foram utilizados dois grupos
de 6 caprinos para determinar a possibilidade de induzir aversão
alimentar condicionada à ingestão de P. eneofusca. Para induzir
aversão alimentar condicionada no grupo $1,0.35 \mathrm{~kg}^{-1}$ de folhas

verdes da planta foram administradas a seis caprinos nos dias 1, 5, 10, 20, 30, 60, e 90 do experimento. No primeiro dia, todos os caprinos ingeriram toda a planta oferecida e foram tratados imediatamente com $175 \mathrm{mg} \mathrm{kg}^{-1}$ de carbonato de lítio ( $\mathrm{LiCl}$ ) através de sonda ruminal. No dia 5, somente dois caprinos ingeriram a planta e foram tratados com a mesma dose de LiCl. Nos dias 10, 20, 30, 60, e 90 nenhum caprino ingeriu a planta. Seis caprinos do grupo controle receberam $0.35 \mathrm{~g} \mathrm{~kg}^{-1}$ de folhas nos dias 1,10 , 20, 30, 60, e 90. Todos os caprinos ingeriram as folhas no dia 1 e foram tratados com $1 \mathrm{ml} \mathrm{kg}$ pv de água mediante sonda ruminal. Todos os caprinos deste grupo tornaram a ingerir a planta nos dias 10, 20, 30, 60 e 90. Esses resultados demonstram que é possível induzir aversão alimentar condicionada à P. aeneofusca, que persiste por pelo menos 90 dias. Próximos experimentos deverão ser realizados para determinar a duração da aversão e para induzir aversão contra outras espécies de Palicourea, particularmente $\boldsymbol{P}$. marcgravii, que é a planta tóxica mais importante do Brasil.

$\begin{array}{ll}\text { Palavras-chave: } & \begin{array}{l}\text { plantas tóxicas, Palicourea spp., } \\ \text { monofluoroacetato de sódio, aversão }\end{array}\end{array}$ alimentar condicionada.

Palicourea aeneofusca (Müll. Arg.) Standl., known as cafezinho or erva-do-rato, causes sudden death associated with exercise in cattle in the coastal regions of Pernambuco, Bahia, Alagoas, and Paraíba (VASCONCELOS et al., 2008). Experimentally administered P. aeneofusca is toxic to cattle, rabbits and goats (PASSOS, 1983). Its toxicity is caused by sodium monofluoroacetate (MFA), which inhibits aconitate hydratase, one of the tricarboxylic acid cycle enzyme (LEE et al., 2012). Among the plants that contain MFA, those from the

\footnotetext{
'Laboratório de Caprinocultura, Centro de Ciências Humanas, Sociais e Agrárias (CCHSA), Universidade Federal da Paraíba (UFPB), Bananeira, PB, Brasil.

IH Hospital Veterinário, Universidade Federal de Campina Grande (UFCG), CP 64, 58700-000, Patos, PB, Brasil. E-mail: rmtmed@uol.com.br. *Autor para correspondência. 
Rubiaceae family, including Palicourea marcgravii, Palicourea grandiflora, Palicourea juruana, and $\boldsymbol{P}$. aeneofusca, are the main toxic plants in Brazil that affect livestock. P. marcgravii occurs throughout most of Brazil, except in states of the southern region, the State of Mato Grosso do Sul, and the semiarid region of Northeastern Brazil, and is the most important toxic plant with Brazil (TOKARNIA et al., 2012). The lethal dose of fresh P. aeneofusca leaves for goats and cattle (TOKARNIA et al., 1983) is 0.6 and $0.75 \mathrm{~g} \mathrm{~kg}^{-1}$ of body weight $\left(\mathrm{g} \mathrm{kg}^{-1}\right)$, respectively. The toxicity of P. marcgravii was found to be similar, i.e., 0.5 to $0.6 \mathrm{~g}$ $\mathrm{kg}^{-1}$, in different experiments using cattle, goats, and sheep. In addition to its wide geographical distribution and high toxicity, intoxication by $\boldsymbol{P}$. marcgravii is also due to its high palatability, which makes animals consume it even when it is sparse. $\boldsymbol{P}$. marcgravii has a cumulative effect when administered daily, but after consuming the plant, the MFA that it contains seems to be detoxified in 2-5 days (TOKARNIA et al., 2012). The clinical signs shown by animals that have been poisoned by Palicourea spp. are tachycardia, jugular engorgement with a venous pulse, tachypnea, a staggering gait, falls, and recumbence, followed by death. No significant macroscopic lesions have been reported. Histologically, the only significant lesions are vacuolar hydropic degeneration and pyknosis of the epithelial cells in the distal convoluted tubes of the kidneys (PASSOS, 1983).

Conditioned food aversion is a technique used with ruminants and horses to prevent their ingestion of poisonous plants. To accomplish this, the emetic substance lithium chloride $(\mathrm{LiCl})$ is administered through a ruminal fistula or gastric tube immediately after the animal consumes the plant; the animal associates the illness caused by $\mathrm{LiCl}$ with the taste of the food and subsequently avoids that taste (RALPHS et al., 2001). In Brazil, conditioned food aversion has been used experimentally to prevent the ingestion of Leucaena leucocephala (GÓRNIAK et al., 2008), Amorimia (Mascagnia) rigida (BARBOSA et al., 2008) and Ipomoea carnea subsp. fistulosa (PIMENTEL et al., 2012). Field experiments have demonstrated the usefulness of this technique on commercial farms to prevent the intake of Turbina cordata and I. carnea (PIMENTEL et al., 2012; OLIVEIRA et al., 2013). These low-toxicity plants are offered in repeated daily doses to induce aversion, and $\mathrm{LiCl}$ is administered each time the animals ingest the plants (PIMENTEL et al., 2012). There are no studies demonstrating the possibility of inducing aversion to plants that are highly toxic and have a cumulative effect, such as Palicourea spp.
This study aimed to determine whether it is possible to induce aversion to $\boldsymbol{P}$. aeneofusca by administering very low doses of the plant (approximately 50\% of the toxic dose) at intermittent periods, allowing MFA to be detoxified in the intervals between each administration.

The experiment was conducted in the Laboratory of Goat Science, at the Federal University of Paraíba (UFPB) located in the city Bananeiras, Paraíba. The plants were collected at the Center for Agricultural Sciences of the UFPB in the city of Areia, Paraíba (S0704'02” W37 ${ }^{\circ} 16^{\prime} 51^{\prime \prime}$ and at an altitude of $567 \mathrm{~m}$ above sea level). The plants were collected the day before use, packed in nylon bags, and stored under refrigeration until administration. The MFA concentration in samples of $\boldsymbol{P}$. aeneofusca collected in the same location was $0.09 \pm 0.05 \%$ (LEE et al., 2012). Twelve 12- to 18-month-old Saanen goats were used in the experiment. The goats were divided into two groups of six animals. The goats in Group 1, weighting $18,19,25,23,18$, and 25kg, were averted with $\mathrm{LiCl}$ after ingesting $\boldsymbol{P}$. aeneofusca, and the goats in Group 2, weighting $18,24,18,31,17$, and $24 \mathrm{~kg}$, received water after first consuming the plant. Each goat was placed in an individual pen. During the experiment, the animals received Pennisetum purpureum ad libitum and $300 \mathrm{~g} \mathrm{day}^{-1}$ of a concentrate consisting of $40 \%$ ground corn, 20\% soybean meal, 20\% wheat bran and $20 \%$ cottonseed meal.

Before aversion treatment, the animals were fasted for 12 hours. They were then each weighed, and green leaves of $\boldsymbol{P}$. aeneofusca at a dose of $0.35 \mathrm{~g} \mathrm{~kg}^{-1}$ were administered during 10 minutes. The goats in Group 1 that ingested the plant were treated within 10 minutes with $175 \mathrm{mg} \mathrm{kg}^{-1}$ of $\mathrm{LiCl}$ administered through a gastric tube. The $\mathrm{LiCl}$ solution contained $175 \mathrm{mg}$ of $\mathrm{LiCl}$ per $1 \mathrm{~mL}$ of water. The leaves were offered on days $1,5,10,20$, 30, 60, and 90. The goats in Group 2 (control) were fed $0.35 \mathrm{~g} \mathrm{~kg}^{-1}$ of leaves of $\boldsymbol{P}$. aeneofusca on days $1,10,20,30,60$, and 90 . On the first day on which the plant was offered, plant ingestion was followed by the administration of $1 \mathrm{~mL} \mathrm{~kg}^{-1}$ of water through a gastric tube. After the administration of $\mathrm{LiCl}$ or water, the animals were observed for the presence of any clinical signs and the heart and respiratory rates were evaluated.

On the first day of the experiment, all of the goats in Group 1 spontaneously ingested all of the P. aeneofusca leaves offered $\left(0.35 \mathrm{~g} \mathrm{~kg}^{-1}\right)$ and were immediately treated with $\mathrm{LiCl}$. On the fifth day, only two animals ingested the leaves and were treated with $\mathrm{LiCl}$. On days 10, 20, 30, 60, and 90, none of the 
animals in this group ate the plant. All of the goats in Group 2 ingested all the leaves on day 1 and received $1 \mathrm{~mL} \mathrm{~kg}{ }^{-1}$ of water through a gastric tube. On days 10 , $20,30,60$, and 90 , all of the animals ingested all of the leaves offered. Clinical signs were not observed in any goat from both groups during the experiment.

These results indicate that it is possible to efficiently induce conditioned food aversion to P. aeneofusca. Prior to this experiment, the main limitation to the use of conditioned food aversion for the prophylaxis of poisoning by this plant was its high toxicity, which limited the amount of the plant that could be offered before the administration of $\mathrm{LiCl}$. In this experiment, the ingestion of only $0.35 \mathrm{~g} \mathrm{~kg}^{-1}$ of the plant followed by the administration of $\mathrm{LiCl}$ was extremely effective in inducing aversion; a single administration to four of the six goats in Group 1 and two administrations to the remaining two animals induced aversion. The other important result was that the aversion persisted during the 90 days of experiment, despite the extreme palatability of the plant. In a study on inducing aversion to Leucaena leucocephala in goats, which is highly palatable, the amount of the plant the treated goats consumed was considerably reduced, but they continued consuming small amounts of it (GÓRNIAK et al., 2008).

Field experiments should be conducted to test the efficacy of applying conditioned aversion to $\boldsymbol{P}$. aeneofusca and other species of Palicourea, particularly $\boldsymbol{P}$. marcgravii, which is the major toxic plant in Brazil (TOKARNIA et al., 2012). Obviously, it is essential to establish whether the dose of $0.35 \mathrm{~g} \mathrm{~kg}^{-1}$ is not toxic to the animals before starting the aversion process in a herd. In this experiment, aversion lasted at least 90 days. Studies with other plants demonstrated that aversion lasted up to three years (RALPHS \& PROVENZA, 1999). Studies conducted in Northern and Northeastern Brazil demonstrated that it is possible to induce aversion to Turbina cordata and Ipomoea carnea that persists for periods of up to two years (OLIVEIRA et al., 2013).

In conclusion, it is possible to use conditioned food aversion to prevent the consumption of and intoxication by $\boldsymbol{P}$. aeneofusca, and most likely, this technique can be applied to prevent ruminants from consuming $\boldsymbol{P}$. marcgravii. Field experiments should be conducted to confirm these possibilities.

\section{ETHICS COMMITTEE}

The experiment was approved be the ethical committee on animal experimentation on the UFCG, process CEP 69-2013.

\section{ACKNOWLEDGEMENTS}

This work was financially supported by the National Institute for Science and Technology for the Control of Plant Poisonings (Grant 573534/2008-0).

\section{REFERENCES}

BARBOSA, R.R. et al. Development of conditioned taste aversion to Mascania rigida in goats. Pesquisa Veterinária Brasileira, v.28, p.571-574, 2008. Available from: <http://www.scielo.br/ scielo.php?script $=$ sci_abstract\&pid=S0100-736X20080012000 01\&lng=pt\&nrm=iso\&tlng=pt>. Accessed: Jul. 17, 2012. doi: 10.1590/S0100-736X2008001200001.

GORNIAK, S, et al. A note on averting goats to a toxic but palatable plant, Leucaena leucocephala. Applied Animal Behaviour Science, v.111, p.396-401, 2008. Available from: <http://www.journals.elsevierhealth.com/periodicals/applan/ article/S0168-1591\%2807\%2900189-X/abstract>. Accessed: Apr. 14, 2011. doi: 10.1016/j.applanim.2007.06.005.

LEE, S.T. etal. Detection ofmonofluoracetatein Palicourea andAmorimia species. Toxicon, v.60, p.791-796, 2012. Available from: <http://www. sciencedirect.com/science/article/pii/S0041010112005065>. Accessed: Aug. 12, 2012. doi: 10.1016/j.toxicon.2012.05.029.

OLIVEIRA, C.A. et al. Intoxicação por plantas que contêm swainsonina no Brasil. Ciência Rural, v.43, n.4, p.653-661, 2013. Available from: <http://dx.doi.org/10.1590/S010384782013000400014>. Accessed: Aug., 12 2013. doi: 10.1590/ S0103-84782013000400014

PASSOS, D.A. Intoxicação experimental em caprinos (Capra hircus) por Palicourea aeneofusca (M. Arg.) Standl. (Rubiaceae). 1983. 40f. Dissertação - Universidade Federal de Pernambuco, Recife, PE.

PIMENTEL, L.A. et al. Aversão alimentar condicionada no controle de surtos de intoxicações por Ipomoea carnea subsp. fistulosa e Turbina cordata em caprinos. Pesquisa Veterinária Brasileira, v.32, n.8, p.707-714, 2012. Available from: <http:// www.scielo.br/scielo.php?script $=$ sci arttext\&pid=S0100-736X20 12000800005\&lng=pt\&nrm=iso>. Accessed: June, 23, 2012. doi: 10.1590/S0100-736X2012000800005.

RALPHS, M.H.; PROVENZA, F.D. Conditioned food aversion: principles and practices, with special reference to social facilitation. Proceedings Nutritional Society, v.58, p.813-820, 1999. Available from: <http://journals.cambridge.org/action/disp layAbstract? fromPage $=$ online\&aid $=797684>$. Accessed: Apr. 21, 2011. doi: 10.1017/S002966519900110X

RALPHS, M.H. et al. Conditioned food aversion: from theory to practice. Rangelands, v.23, n.2, p.14-18, 2001. Available from: <http://www.jstor.org/discover/10.2307/4001577?uid=3737664\& uid=2\&uid=4\&sid=21102713265973 > . Accessed: Mar. 26, 2011.

TOKARNIA, C.H. et al. Intoxicação por Palicourea aeneofusca (Rubiaceae), A causa de mortes súbitas em bovinos na Zona da Mata Pernambucana. Pesquisa Veterinária Brasileira, v.3, n.3, p.75-79, 1983.

TOKARNIA, C.H. et al. Plantas tóxicas do Brasil para animais de produção. Rio de Janeiro: Helianthus, 2012. 586p.

VASCONCELOS, J.S. et al. Mortes súbitas em bovinos causadas por Palicourea aeneofusca (Rubiaceae) e Mascagnia rigida (Malpighiaceae) na Zona da Mata Paraibana. Pesquisa Veterinária Brasileira, v.28, p.457-460, 2008. Available from: <http://www.scielo.br/scielo.php?script=sci_arttext\&pid=S0100736X2008001000013\&lng=pt\&nrm=iso >. Accessed: Jul. 11, 2011. doi: 10.1590/S0100-736X2008001000013. 